mountains. These eggs hatch out if exposed to the sun, so they are generaliy carried by night. The method of production of this wax has been fully described by Mr. Hosie.

After travelling through a very wild region, the party reached an elevation of 5000 feet, where $\mathrm{Mr}$. Pratt gathered a lovely fragrant honeysuckle and a fine mauve-coloured primula, and saw some feathers of the famous Amherst pheasant. On May 24 they struck the main stream of the Tung river, which appears to divide the territory of the independent Loios from that of the portion of this interesting people subject to the Chinese. Passing by the side of a range of mountains the party followed an affluent of the Tung river, and on May 26, thirty-two days after leaving Chung-king, reached Ta-tsien-chib, a long straggling village of detached ciusters of houses. It stands at an elevation of 5980 feet above the sea. The mountain ends in a series of fourteen precipices, each some 200 feet high, the bighest being only accessible by ladders. The climate is very much like that of England-cold, rainy, and changeable; the roses very pretty. but single, and strawberries were plentiful; and there is good shooting - wild ox, two species of antelope, two species of bear, and five of pheasant.

The party went on to Ta-chien-lu, the road leading over a pass some 10,000 feet in height. Ta-tsien-lu is a most interesting town. All sorts of Asiatics may be met in its streets, and Europeans, therefore, attract less attention here than in other places where strangers are seldom seen. The natives of the place are the wildest-looking people, invariably armed to the teeth; some of fine physique, tajl and handsome, with long matted hair hanging over their faces.

The following year, $18 \mathrm{go}$, Mr. Pratt made a second expedition to Ta-tsien-lu, to increase his collections. This time be carried out the intention he had formed on his previous journey, of ascending Mount Omei. This mountain is II, IOO feet bigh, and is regarded throughout the neighbouring countries as a spot of peculiar sanctity. There are between sixty and eighty temples on it, and about two thousand priests, and it is coninually visited by many thousands of pilgrims. The mountain rises abruptly like a promontory, and can only be ascended from one side. The others are extremely steep, one of them being a precipice nearly a mile and a third high, the highest sheer declivity, perhaps, in the world. As the party approached the mountain, they passed many fine trees, of the species allied to the banyan. One particulariy fine specimen, with a magnificent spread of foliage, Mr. Pratt measured, and found it to be 30 feet in circumference. The path led them at first through a wide fertile valley of rice fields, with clumps of trees scattered here and there as in a park. The mountain is covered from head to foot with undergrowth and forest, pines, bollies, and other evergreens predominating. Flowers were very abundant, wild roses, anemones, asters, yellow violets, and two species of hydrangea, Here Mr. Pratt noticed Paxia begonia, which he believes has no representative in Europe, but which he believes is represented in America. Near the top he found a primula and a dwarf azalea with fragrant foliage, the latter, so far as he knows, a unique specimen.

During this visit, Mr. Prattmore that once witnessed the curious phenomenon known as the glory of Buddha. Standing on the edge of the precipice, and looking down into the sea of mist which generally fills the valley below, he saw, abont $I 50$ feet beneath him, the gotden disk surrounded by rainbow-coloured rings of light, which is the chief marvel of Mount Omei, and the clearest evidence of its sanctity. Every year many pilgrims commit suicide by throwing themselves down from this cliff. On May I, accompanied by Father Soulić, Mr. Pratt made an excursion from Ta-tsien-lu to the snow-capped mountains, and pitched his tent in a forest of rhododencrons just coming into bloom, about two hours below the region of perpetual snow.

By way of summary of the vegetation, Mr. Pratt divides the country here briefly into four regions or zones:-(I) Above I6,000 feet we have perpetual snow. (2) Between 16,000 feet and 10,000 feet, rhododendroris, anemones, primulas, rhubarb, many lities, a few asters, grass, and wild onions; of birds, Crossottilon thibetanum, Lophophorus lhuysii, and Père David's small biue bird. (3) From 10,000 to 5000 feetrhododendrons, coniferous trees, gooseberries, several species of currant (including one very large black currant with bunches of fruit a foot in length), undergrowth, and several species of birds. (4) Below 5000 feet there is cultivation on a few farms, and pasturage.

$$
\text { NO. I I } 20 \text {, VOL. } 43 \text { ] }
$$

\section{GRZIMAILO'S EXPEDITION.}

N March 25, the Russian Geographical Society held an extraordinary meeting to listen to a communication by $\mathrm{G}$. E. Grum.Grzimailo about his expedition to Central Asia. The expedition consisted of M. Grum-Grzimailo, his brother, a collector, an interpreter, six Cossacks, and two men. The luggage was transported on some fifty horses and donkeys. After having crossed the Russian frontier on June 8,1889 , they soon reached Kulja, and thence went north-east, towards the spurs of the Boro-Khoro Mountains. By the way they visited Central Djungaria, in order to obtain specimens of the wild horse dis. covered by Przevalsky, and described as Equas praevalski by the late Polyakoff from one single specimen brought in by the great traveller. Four specimens more were obtained. Returning from Djungaria, the expedition proceeded, in September, to the Eastern Tian-Shan, and completed the exploration of its remotest eastern parts. The well-known oasis of Turfan proved to be a desert which has been recovered for industry only by the hardest imaginable labour. It has no water, notwithstanding the proximity of the snow-mountains of Bogdo; and its inhabitants have dug out a whole system of underground canals and wel's (some of which are 300 feet deep) to irrigate the desert. The canals collect the water underground, and then bring it to the surface in the lower grounds. The whole work is so colossal that the members of the expedition compare it with the colossa works of Egypt. As to the absolute height of the oasis, $M$. Grum-Grzimailo pointed out that parts of it appear to be belono the level of the sea. Of course, this conclusion of the Russian traveller, being based upon barometrical measurements only, cannot yet be taken as quite certain; but it shows that the oasis of Turfan is extremely low, and that it in no case rises more than from 200 to 300 feet. It thus must represent the bottom of a great lake, which oscupied on the border of the Central Asian plateau the same position as Lake Baikal occupies now; and this quite unexpected fact is ore of great importance for the physical geography and geology of the whole region.

In February $189^{\circ}$ the expedition reached $\mathrm{Hami}$, and thence proceeded to Mor-gol. Heavy snowfalls, however, prevented their further advance eastwards; so they turned towards the sonth, and went to the Nian-Shan ridge, which had already been crossed in :hree different places by Przevalsky and Potanin. MM. Grum-Grzimailo studied that interesting ridge over a length of 300 miles, and crossed it in a picturesque gorge which brought them to the Babo-ho river, and thence to the Chinese town Yunan-tcheu. After having explored the Alps of Si-nin, they reached the Hoang-ho, and thence began their return journey. The snowstorms rendered travelling difficult, so they rested for a while at Su-tcheu, and thence, crossing the Be-tchan Mountains, went to Gu-tchen, thence to Urumtchi, and finally reached the Russian frontier on November 25,1890 Survey has been made over a length of 4840 miles, of which 4000 miles were previously untrodden ground; latitudes and longitudes were often determined during the journey; so also were altitudes. Nearly 200 photographs were taken, and the natural history collections are sure to be very interesting.

\section{SCIENTIFIC SERIALS.}

American Foumal of Mathematics, vol. xiii., Nos. 2 and 3.In No. 2 is concluded Part I. of a lengthy article by $O$. Bolga on the theory of substitution-groups and its application to algebraical equations; the final section discusses groups of operations, especially those obtained from the "groups" of rotations of a regular polyhedron which leave it congruent with its first position. Part II. deals with Galois' theory of algebraic equations."-The following papers also appear:"Quelques propriétés des nombres $\mathrm{K}_{m}^{p}$ " by M. M. d'Ocagne. These numbers have been discussed in a previous article ( 1887, p. 353), where they were defined by means of a triangle analogous to Pascal's.--_" Sur les lois de forces centrales faisant décrire ì leur point d'application une conique quelles que soient les conditions initiales," by P. Appell.-On certain identities in the theory of malrices, by $\mathbf{H}$. Taber, Systems of rays normal to a surface, by W. C. L. Gorton,-On the epicycloid, by F. Morley. Some interesting results of 